\title{
Actualidades económicas y financieras del turismo receptor del Perú durante la década de 1990
}

\section{José Manuel Marsano Delgado}

\section{I.-Introducción}

¡Qué década la que nos tocó vivir!, ésta que ya se fue de los noventa. Década que se caracterizó en sus primeros años por haber atravesado por una profunda depresión en la industria del turismo. Esto obligó a los empresarios a asumir riesgos que, en mi opinión, los enriquecieron tanto en imaginación como en creatividad a efectos de que sus empresas pudieran, literalmente, sobrevivir.

Es que nadie que tenga a bien leer este artículo podrá olvidar los difíciles años vividos como consecuencia de aquella triste violencia desatada en el país por los grupos terroristas. Años en los que el Perú fue calificado, no sólo por las agencias gubernamentales de muchos países encargadas de velar por la seguridad de sus conciudadanos sino también por aquellas dedicadas a evaluar el riesgopaís, como un destino de altísimo riesgo, tanto para ser visitado como para invertir en él. Me refiero en particular al período 1988-1993.

\section{II.-Impacto económico}

El impacto económico fue tan perverso para el turismo receptor que, si analizamos las tasas de crecimiento para el período 1988-1993, veremos que éstas fueron negativas en un $5,14 \%$ anual, habiendo decrecido $22,47 \%$ en términos acumulados (ver cuadro número uno).

\author{
Cuadro $n^{\circ} 1$ \\ Turismo receptor \\ 1988-1993
}

\begin{tabular}{|c|c|}
\hline Año & Total de visitantes \\
\hline 1988 & 359000 \\
\hline 1989 & 334000 \\
\hline 1990 & 316871 \\
\hline 1991 & 232012 \\
\hline 1992 & 216534 \\
\hline 1993 & 271901 \\
\hline
\end{tabular}

Fuente: Badatur

El punto de quiebre, es decir, aquel en que la tasa de crecimiento se convirtió en negativa, fue el correspondiente al año 1992. 
El impacto económico fue muy severo en los ingresos por concepto de divisas, tanto en el ámbito de las cuentas nacionales, como de los ingresos empresariales del sector.

Si analizamos los ingresos por concepto del turismo receptor, durante el período 1988-1993, notaremos que la tasa de crecimiento fue negativa en $3,13 \%$ anual, mostrando una tasa acumulada de $14,70 \%$ (ver cuadro número dos).

\section{Cuadro $n^{\circ} 2$ Ingresos}

\begin{tabular}{|c|c|}
\hline Año & $\begin{array}{c}\text { Ingresos en millones } \\
\text { de dólares }\end{array}$ \\
\hline 1988 & 252 \\
\hline 1989 & 248 \\
\hline 1990 & 217 \\
\hline 1991 & 225 \\
\hline 1992 & 156 \\
\hline 1993 & 215 \\
\hline
\end{tabular}

Fuente: Badatur

No obstante, a partir del 1993, el país fue paulatinamente recuperando la tan ansiada tranquilidad social y, gracias a ello, las agencias gubernamentales y las calificadoras de riesgo-país, fueron clasificando al Perú como un destino de poco riesgo, tanto para ser visitado como para invertir en él y, en consecuencia, vimos el resurgir de tan golpeada industria.

Para el período 1993-1999, la tasa anual promedio de crecimiento fue de $23,05 \%$, en tanto que la tasa acumulada para similar período fue de $247,19 \%$. Ambas permitieron un crecimiento alentador del sector (ver cuadro número tres).
Cuadro $n^{\circ} 3$

Total visitantes

\begin{tabular}{|c|c|}
\hline Año & Total de visitantes \\
\hline 1993 & $271 \quad 901$ \\
\hline 1994 & $386 \quad 120$ \\
\hline 1995 & 479231 \\
\hline 1996 & 662736 \\
\hline 1997 & 746599 \\
\hline 1998 & $819 \quad 530$ \\
\hline 1999 & 944000 \\
\hline
\end{tabular}

Fuente: Badatur

\section{III.-Balanza de bienes y servicios del sector}

A consecuencia de la paulatina recuperación en el flujo de turistas, como se observa en el cuadro anterior, el ingreso de divisas para el país y a su vez- para el empresariado del sector, mejoró notablemente a partir de 1994, año en que el saldo de la balanza de bienes y servicios del sector se tornó positivo (ver cuadro número cuatro).

\section{Cuadro $n^{\circ} 4$}

Balanza de bienes y servicios del sector turismo (Expresada en millones de dólares)

\begin{tabular}{|c|c|c|c|}
\hline Año & Abonos & Cargos & Saldo \\
\hline 1990 & 217 & 295 & -78 \\
\hline 1991 & 225 & 263 & -38 \\
\hline 1992 & 156 & 255 & -99 \\
\hline 1993 & 215 & 269 & -54 \\
\hline 1994 & 331 & 266 & 65 \\
\hline 1995 & 428 & 297 & 131 \\
\hline 1996 & 670 & 350 & 320 \\
\hline 1997 & 816 & 434 & 382 \\
\hline 1998 & 845 & 452 & 393 \\
\hline 1999 & 890 & 443 & 447 \\
\hline
\end{tabular}

Fuente: Badatur

A partir del año 1993, y hasta 1999, podemos observar que el rubro de abonos a la balanza de bienes y servicios - es decir, los ingresos registrados por concepto de nuestro turismo exportador (gastos que los turistas y visitantes de otros países realizan en el Perú, excluyendo los costos de pasajes desde y hacia sus lugares de origen) - experimentó un crecimiento promedio anual de $28,24 \%$, habiendo sido el crecimiento acumulado para igual período de $470,51 \%$. 
En lo referente al rubro cargos (gastos que nuestros turistas realizan en el exterior, sin considerar el valor de los pasajes) vemos que el promedio anual, a partir del 1993 , fue de $8,21 \%$, habiendo ascendido el crecimiento acumulado, con relación al año 1993 , en un $73,73 \%$.

Al comparar tanto las tasas de crecimiento anuales de nuestros ingresos como las acumuladas podemos inferir que la balanza de bienes y servicios del sector fue sumamente favorable para el país, ya que el margen de crecimiento neto de divisas para el período en mención ascendió a 396,78\%. Ello significó no sólo un gran alivio económico sino nuevas inversiones en infraestructura de planta.

\section{IV.-Los efectos positivos macroeconómicos del turismo en la economía}

El primer efecto que se observa es el incremento del ingreso nacional, vale decir el producto bruto interno. Si consideramos el mismo, teniendo en cuenta el cambio del año base del PBI (año 1994), la participación del turismo receptor en el producto nacional se estima en $4,1 \%$, por lo que si consideramos nuestro PBI (teniendo en cuenta el citado año base), para el año 1999, ascendió a US\$52000 millones, lo que significó que el PBI del sector turismo ascendió a la suma de US\$2132 millones, cifra bastante interesante para la economía si consideramos que el mismo es un amplio generador de mano de obra.

El segundo efecto lo podemos ver en el incremento en la participación del turismo receptor en el total de nuestras exportaciones. Así, para el año 1993 el sector turismo genera un 6,11\% del total de las exportaciones, mientras que para los años sucesivos el comportamiento fue el siguiente: $1994: 7,20 \%$; 1995: 7,66\%; 1996: 11,36\%; 1997: $11,94 \%$; $1998: 14,73 \%$ y $1999: 14,56 \%$. Es importante resaltar que el crecimiento promedio, dentro del rubro de nuestras exportaciones, para el período comprendido entre 1993-1999 fue del $15,57 \%$ anual, tasa que en términos acumulados significó un incremento, con relación al año 1993, de $138,29 \%$.

Un tercer efecto es la generación de divisas inherentes al comercio exterior, ya que para los fines del caso, el turismo receptor se ha convertido en un ente generador de divisas. Para ello recomendamos revisar el cuadro número cuatro en el cual se podrán observar los resultados, tanto del turismo emisor como del receptor, y el resultado neto del sector.

Partiendo de una infraestructura hotelera pobre e insuficiente a inicios de los noventa, las inversiones en infraestructura de planta tuvieron un efecto multiplicador en la economía. Así, la inversión extranjera en el período 19901999 ascendió a un total de US\$247 millones, habiendo experimentado una tasa de crecimiento anual de $17,29 \%$.

\section{V.-El costo per cápita del turismo receptor peruano}

Definiremos el costo per cápita del turismo receptor como aquel gasto en el que incurre un turista o visitante que llega a nuestro país, permaneciendo un tiempo promedio no superior a los trece días. En dicho gasto no se encuentran incluidos los costos de pasajes de ida y vuelta.

Este gasto, para el período 1990-1999, expresado en dólares, experimentó una tasa de crecimiento de $3,62 \%$ anual y un incremento acumulado de $37,66 \%$. Es decir, el costo para el visitante, en iguales períodos promedio de permanencia en el país y realizando básicamente el mismo tipo de turismo, el histórico-cultural, se ha encarecido progresivamente, tal como se señala en el párrafo anterior y constata en el cuadro número cinco.

\section{Cuadro $n^{\circ} 5$}

Gasto per cápita

\begin{tabular}{|c|c|c|c|}
\hline Año & $\begin{array}{c}\text { Ingresos } \\
\text { en millones } \\
\text { de dólares }\end{array}$ & $\begin{array}{c}\text { Cantidad } \\
\text { de } \\
\text { turistas }\end{array}$ & $\begin{array}{c}\text { Gastos } \\
\text { per cápita } \\
\text { en dólares }\end{array}$ \\
\hline 1990 & 217 & 316871 & 685 \\
\hline 1991 & 225 & 232012 & 970 \\
\hline 1992 & 156 & 216534 & 720 \\
\hline 1993 & 215 & 271901 & 791 \\
\hline 1994 & 331 & 386901 & 857 \\
\hline 1995 & 428 & 479231 & 893 \\
\hline 1996 & 670 & 662736 & 1011 \\
\hline 1997 & 816 & 746599 & 1093 \\
\hline 1998 & 845 & 819530 & 1031 \\
\hline 1999 & 890 & 944000 & 943 \\
\hline
\end{tabular}

Fuente : Badatur 
En mi opinión, el encarecimiento del turismo receptor obedeció a un factor principal que se explica a continuación.

El retraso cambiario que se suscitó en la economía, a partir del año 1991, y que se acentuó durante los siguientes años, produjo una brecha entre inflación y devaluación interna para el período 1991-1999 del orden de 254,69\%. Lamentablemente, el país no cuenta con una tabla de insumo producto del sector a efectos de medir con exactitud el efecto de tal distorsión, pero es evidente que la misma afectó los costos operativos de las empresas ligadas al turismo, elevándolos en términos de dólares sin que la industria turística pudiera compensar la distorsión.

Otro factor que influyó, y sigue influyendo en el costo de nuestro turismo receptor, es el aspecto tributario. Hay que recordar que el turismo receptor, por definición, es un servicio que se exporta y que, por lo tanto, en lo que compete al tratamiento tributario, debe de ser igual al que se le da a cualquier exportación que se realiza.

Debemos recordar que las ventajas comparativas que el Perú gozó, durante más de cuatro décadas, se están diluyendo ya que con los factores inherentes a la globalización como son los medios de comunicación masivos (caso del Internet), nuestro turismo compite con una serie de países tan ricos como el nuestro en lo que se conoce como turismo histórico-cultural, con el añadido de que muchos de los mismos han incrementado su oferta combinándolo con turismo de ocio y de aventura, y a costos mucho más competitivos.

No debemos olvidar que los turistas que nos visitan, en un gran porcentaje, provienen de países del primer mundo, cuyas economías se caracterizan por ser sumamente sólidas y con factores inflacionarios muy bajos, por lo que un índice de incremento en el costo per cápita del orden del $5 \%$ anual, como el que experimentó el sector durante la década del noventa, es altamente perjudicial para el futuro del turismo receptor.

\section{VI.-Las proyecciones del turismo receptor}

De acuerdo a las proyecciones efectuadas por el Instituto de Investigaciones de la Facultad de
Turismo y Hotelería de la Universidad de San Martín de Porres, a través de su banco de datos turísticos -Badatur Perú-, los turistas o visitantes esperados para el período 2001-2005, considerando la tendencia del turismo receptor en los últimos ocho años, será el siguiente:

\section{Cuadro $n^{\circ} 6$ \\ Turismo receptor proyectado}

\begin{tabular}{|l|c|}
\hline Año & Turismo receptor proyectado \\
\hline 2001 & 1158851 \\
\hline 2002 & 1266124 \\
\hline 2003 & 1377397 \\
\hline 2004 & 1486670 \\
\hline 2005 & 1595942 \\
\hline
\end{tabular}

Fuente: Badatur

Estas proyecciones consideran que no se presenten en el país perturbaciones sociales de ninguna naturaleza, las cuales no sólo desvían las corrientes turísticas hacia otros países cuya oferta es similar a la nuestra, sino que alejan a los inversionistas. Según el cuadro podemos suponer que el crecimiento anual esperado para el período 2001-2005 será de $9,22 \%$, en tanto que el crecimiento acumulado para igual período ascenderá a $55,42 \%$.

Estimo que no deberá sorprender al lector el crecimiento de la tasa anual de del turismo receptor en comparación a la experimentada en el período 1993-1999, pues no debemos olvidar que, por efecto de la convulsión social vivida en el país, se produjo una acumulación de demanda no satisfecha. Luego del proceso de pacificación, por una parte, y de la apertura económica a la inversión extranjera, por otra, - fenómeno que, para los que vivíamos en el país nos daba la sensación de haber salido de una economía "autárquica" debido a la oferta de nuevos productos sobre todo en el rubro de servicios- es que podemos observar que las tasas de crecimiento de turistas o visitantes en el período 1993-1999, así como la proyectada, muestran un diferencial de $191,77 \%$.

No obstante, la tasa anual de crecimiento esperado de nuestro turismo receptor se mantendrá por 
encima de la tasa de crecimiento mundial para igual período, la cual se estima en $3,16 \%$ anual, según las estimaciones efectuadas por el mismo instituto.

\section{VII.-Conclusiones}

En una economía globalizada, donde los medios de comunicación juegan un papel importantísimo en la formación de la opinión pública mundial con una rapidez inusitada, es esencial cuidar tanto la imagen interna como la externa del país.

La opinión mundial tiene en la actualidad a su disposición una serie de medios para enterarse de las seguridades que en lo personal, así como en lo financiero y económico, puede ofrecer un determinado país receptor.

En el campo del turismo ya hemos experimentado el impacto de una convulsión social que estuvo a punto de quebrar la totalidad de esta industria, haciéndonos perder muchos mercados y permitiendo que, al amparo de ello, surgieran nuevos países ofertantes, atrasándonos en lo referente a la generación de infraestructura de planta en comparación con otros países que tienen similar ofertan turística que Perú.

Debemos tener mucho cuidado en el tratamiento que el gobierno debe dar al sector. No olvidemos que el turismo receptor es un rubro más de nuestras exportaciones, porque en realidad es un servicio que vendemos al exterior a través de las visitas que realizan los ciudadanos de otros países al Perú.

En ello, las políticas tributarias, así como los incentivos que el Estado pueda ofrecer, sin caer en la demagogia de subsidios anti-técnicos, serían los medios más recomendables para impulsar el sector.

En lo referente a la oferta turística, el país, en un $94 \%$, ofrece un turismo histórico-cultural. Es cierto que siempre tuvimos ventajas comparativas en este campo, pero no es menos cierto que muchos países, con similares características que el nuestro en cuanto al tipo de turismo, han evolucionado y ampliado su abanico de oferta, combinando el turismo histórico-cultural con otros como el de aventura y el recreacional.
Nuestro país debe seguir estos ejemplos ya que, de lo contrario, en un corto plazo nos podríamos encontrar con ingratas sorpresas.

Debemos tener presente que en las economías modernas las ventajas comparativas no necesariamente se han obtenido por herencia. Con ello me refiero al turismo recreacional o de ocio, el turismo de aventura y muchos otros, que poniendo al servicio de la industria turística la aplicación de tecnologías de punta, han logrado convertir regiones de sus territorios en verdaderos paraísos turísticos.

Finalmente, no quisiera dejar de mencionar los beneficios desde el punto de vista macroeconómico, ya que una adecuada política de inversiones en el sector, que cuente con una planificación de carácter indicativa nos permitiría, a través del efecto multiplicador que la misma conlleva, generar nuevos puestos de trabajo, tan necesarios para el crecimiento económico del país en los momentos actuales. En concordancia con lo antes expuesto, tengamos en cuenta el elevado efecto distributivo del ingreso bruto de esta industria, la cual se caracteriza por ser altamente intensiva en el uso de mano de obra.

\author{
José Manuel Marsano Delgado \\ Instituto de Investigación \\ Facultad Turismo \\ Universidad de San Martín de Porres \\ Lima, Perú \\ imarsa@fccsmp.edu.pe
}

